\title{
Analysis of the digital divide of information literacy for rural-urban in Taiwan
}

\author{
H. S. Chang ${ }^{1} \&$ K. W. Tsou ${ }^{2}$ \\ ${ }^{I}$ Department of Local Development and Management, Leader University, \\ Taiwan \\ ${ }^{2}$ Department of Urban Planning, National Cheng-Kung University, \\ Taiwan
}

\begin{abstract}
Information communication technologies (ICT) can eliminate many of the obstacles of time and space and help overcome gaps in regional development. However the arrangement of advantages brought by ICT is uneven, and this is what gives rise to the phenomenon of a "digital divide". As to the current status in Taiwan, information technologies have been highly developed in recent years and the conditions of information facilities and accessibility in various areas are now more consistent. However, a digital divide of qualitative capability in information literacy and the capability of utilizing information by individuals obviously remains. Therefore in this article, we examined the current status of information literacy of students in primary schools in a southern county in Taiwan using influential factors as focal points to gather data by means of questionnaire surveys. At the same time, we employed the framework of the local environment, information settings, and individual backgrounds to carry out variance analysis in order to understand the current status of the character of digital literacy in Taiwan so that government policies can be adjusted to diminish the digital divide.

Keywords: information communication technologies, digital divide, information literacy.
\end{abstract}

\section{Introduction}

The recent booming expansion of the Internet represents a new era in the information society. The advantages brought by the revolution in information 
technology in developed and developing countries of this new society are unevenly distributed, and this has created a development divide between countries and regions (WSIS, [10]). Society in Taiwan has formally stepped into the information age, and the information capabilities and information literacy of civilians have become indispensable elements for improved living standards. Factors of family income, gender, age, educational level, and differences between urban and rural areas have caused various degrees of discrepancies with network utilization and information accessibility services. These kinds of discrepancies are getting larger and eventually may strengthen inequalities of society, which may create problems of social equality and justice (Irving, [3]).

There are two major viewpoints concerning the issue of the digital divide in the past: one was to probe the accessible usage problem by "quantity capability" and the other one was to describe individual information literacy by the "quality capability". Past research reports on the digital divide in Taiwan showed that the digital divide was getting smaller, which meant that the digital divide in terms of the quantity capability was declining. But the digital divide in terms of information literacy for quality capability is still retained. Current discussions of relevant information literacy emphasize the levels of adults and colleges. Compulsory education of the citizenry is a part of the national fundamental education program, and the effects of having educated citizens will influence the basic capabilities for higher education and national competitiveness. But few studies have examined high school and elementary school students, and some scholars think that computer literacy means information literacy which is incorrect. According to McClure [5], information literacy is comprised of four types: traditional literacy, computer literacy, network literacy, and media literacy. Current studies of primary school students emphasize status quo surveys of computer literacy and the discipline and training education of library literacy, but they lack overall observations.

This study is a response to the development of informationalization and the networking of society and cultivating the future capabilities of primary school students and is based on relevant theories described by many scholars. We used primary school students as the study object in the hope that analyzing the current status of information literacy and its influential factors under existing conditions of the digital divide can provide references for various levels of government, schools, and parents as to ways of diminishing the digital divide and upgrading the information literacy of students.

\section{Research on the current status of the digital divide}

Previous related studies provided different definitions for the digital divide. For example in the study report "Understanding the digital divide, 2001" by the OECD, the digital divide was defined as variations in opportunities existing among individuals, households, enterprises of various social and economic backgrounds or geographic localities, and the accessibility of utilizing information technology and applying it to the Internet to participate in all kinds of activities. In the principal announcement of the WSIS, it was also mentioned 
that the advantages which were brought by the information technology revolution in developed and developing countries and the interior of each society were unevenly distributed and had formed a phenomenon of a "digital divide" (WSIS, [10]). Moreover, domestic scholars consider that the digital divide is caused by variations of geographic segregation, racial groups, economic status, gender, and differences in technology, knowledge, and capability of applying information and communication technologies on the Internet.

In this article, we summarize the relevant studies and found that the factors that contribute to the formation of a digital divide include gender, age group, educational level, income level, racial group, geographic location, and variations between urban and rural areas. If a user wants to change information in the information economy into knowledge in order to develop its function and value, in addition to having a good information infrastructure, facilities, and services, the user must have sufficient information literacy and skills to utilize them. If a user lacks literacy and skills, he will become marginalized in the information society. Therefore the expression of a digital divide should include two dimensions: accessible utilization of information technology, which belongs to the study of quantity capability; and an analysis of the degree of information literacy, which belongs to the study of quality capability.

When observing the phenomenon of the digital divide, one should distinguish differences between quantity capability and quality capability. In the long run, variations between the opportunity to utilize information technologies by the general public and whether or not the constructed infrastructure is perfect or has been improved means that in the near future, improvements of related studies on the quantity capability of the digital divide will eventually be eliminated to be replaced the study of the quality capability of effective information literacy. This study accepts this viewpoint in order to explore the current status of information literacy and the factors influencing primary school students.

\section{Contents of information literacy}

The term "information literacy" was first provided by Zurkowsk who was chairman of the Association of Library and Information Science of America in 1974. He mainly pointed out that individuals have the ability to find, evaluate, and utilize various sources of information which should include five capabilities: 1. knowing what kind of information is helpful; 2 . knowing where to get that information; 3. knowing how to inspect the information; 4. evaluating and organizing the information; and 5. immediately transmitting the information.

McClure thought that information literacy is a concept and also a kind of capability of utilizing information to solve problems. So-called information literacy should include traditional literacy, network literacy, computer literacy, and media literacy (McClure, [5]). Traditional literacy is the basic capability of reading and writing and the skill of utilizing conventional ways to solve information-related problems. Media literacy means being able to apply media skills of other than plane and paper to solve information problems such as 
operating a $\mathrm{CD}$, recording tape, lantern slide, microfilm, etc. (McClure, [5]). Computer literacy is having the experience and capability of operating a computer. Network literacy was classified into two parts of relevant knowledge and discussion skills. Although information literacy was classified into four types, they are mutually influenced and interconnected. From the figure below, one can see that the mutually intersecting parts of the four types of literacy are in the narrowest sense information literacy and the combination of the four types of literacy could refer to the broadest sense of information literacy. Information literacy not only is the core of the four types of literacy but also includes the combination of the four types of literacy. Thus only by possessing all four types of literacy at the same time can it be called information literacy. Therefore these four types of literacy are indispensable.

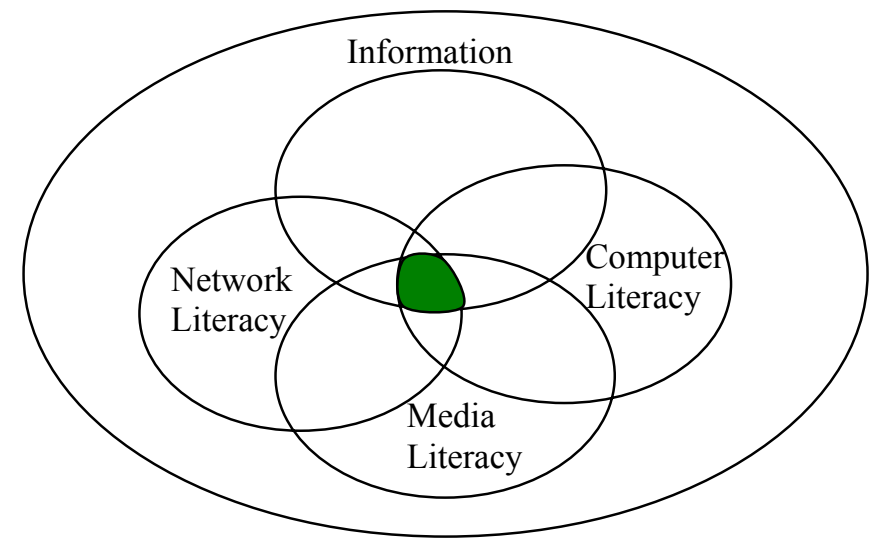

Figure 1: The concept of information literacy (source of data: McClure, [5]).

From the content of applying basic information capability, we found that "utilizing resources of networks and libraries to undertake data collection and make files" belongs to the library literacy capability; and "employing resources of CDs and DVDs to gather data" and "utilizing media of information technology to search for needed data" belong to the media literacy capability. We know that the course design of the nine years of compulsory education in Taiwan emphasizes cultivating computer literacy capability and network literacy capability, but it obviously lacks the learning content design for library literacy capability and media literacy capability which should be strengthened. Traditional literacy is the foundation of other types of literacy; and if lacking library literacy, then the other types of literacy are not well developed. Therefore, cultivating one's literacy capabilities should proceed with all four of them at same time without exception, while simultaneously paying attention to students' capabilities to collect, evaluate, organize, and apply information. The purpose of this article was to explore the degree of information literacy which 
students have and determine how to inspect and measure the factors which influence it.

\section{Study framework}

The most frequently evaluated factors when using students to study information literacy have been variations in their personal backgrounds and differences in the information environment, while the factor of regional variations has seldom been examined. Through a literature review, we found that different expressions of the digital divide exist between regions, thus this article studies information literacy. The most frequently used variables of personal background in relevant studies are gender and age; the most frequently used variables of the information environment are family computer facilities, family network facilities, the amount of time using the related facilities, and seniority of network use. Seldom utilized variables include social and economic status of the family, whether or not has communication objective in the family, and difference of residential areas.

This article uses the influence of "regional variations", "differences in the information environment", and "variations in personal background" of various regions on the degree of information literacy to the phenomenon of the digital divide as the basic study framework. We mainly studied factors of regional variations, differences in the information environment, and background variations of different regions.

\section{Investigation analysis}

This article attempts to probe the development of information literacy by primary school students and to inspect and determine the initial result of the influence on the information literacy of primary school students. The major study object of this article was grade 6 students of primary schools in Tainan County, and based on the arrangement of urban planning districts, classify schools into urban and non-urban districts according to the geographic locality. The sample design used strata sampling and cluster sampling and issued 1200 copies of a questionnaire, of which we received 1185 copies back. The return ratio was $98.8 \%$, and there were 1160 valid questionnaires. The results of questionnaire analysis are described below.

\subsection{Analysis of the current status of information literacy}

Table 1 shows that the overall average score for "information literacy" of primary school students in Tainan County was 21.57 (out of 28) or $77 \%$. "Network literacy" had the highest score (with an average score of 6.51 , or $81.4 \%$ ); "media literacy" was next (with an average score of 5.58, or 79.7\%); followed by "library literacy" (with an average score of 4.76, or 79.3\%); while "computer literacy" had the lowest score (with an average score of 4.71, or $67.3 \%$ ). Therefore, we determined that the overall information literacy degree of primary school students in Tainan County is above the average standard. 
Table 1: Table of score analysis of each type of information literacy of students.

\begin{tabular}{|c|c|c|c|c|}
\hline Type of literacy & $\begin{array}{c}\text { Average } \\
\text { score }\end{array}$ & Full marks & $\begin{array}{c}\text { Percentage } \\
\text { score }\end{array}$ & $\begin{array}{l}\text { Standard } \\
\text { deviation }\end{array}$ \\
\hline Library literacy & 4.76 & 6 & $79.3 \%$ & 1.128 \\
\hline Media literacy & 5.58 & 7 & $79.7 \%$ & 1.446 \\
\hline Computer literacy & 4.71 & 7 & $67.3 \%$ & 1.657 \\
\hline Network literacy & 6.51 & 8 & $81.4 \%$ & 1.577 \\
\hline Information literacy & 21.57 & 28 & $77.0 \%$ & 4.577 \\
\hline
\end{tabular}

The following table shows that the correlation coefficient value of R2 of library literacy, computer literacy, network literacy, and media literacy ranged from 0.405 to 0.611 , which means that each pair of the four types had notable positive correlations $(\mathrm{p}<0.01)$ and the correlation degree of "computer literacy" and "network literacy" were the highest among them.

Table 2: Table of Pearson's correlation coefficient analysis of the percentage scale of information literacy.

\begin{tabular}{|c|c|c|c|c|}
\hline Percentage scale & $\begin{array}{c}\text { Library } \\
\text { literacy }\end{array}$ & $\begin{array}{c}\text { Media } \\
\text { literacy }\end{array}$ & $\begin{array}{c}\text { Computer } \\
\text { literacy }\end{array}$ & $\begin{array}{c}\text { Network } \\
\text { literacy }\end{array}$ \\
\hline Library literacy & 1.000 & - & - & - \\
\hline Media literacy & $0.405^{* *}$ & 1.000 & - & - \\
\hline Computer literacy & $0.411^{* *}$ & $0.530^{* *}$ & 1.000 & - \\
\hline Network literacy & $0.431^{* *}$ & $0.485^{* *}$ & $0.615^{* *}$ & 1.000 \\
\hline${ }^{* *} p<0.01$
\end{tabular}

\subsection{Deviation analysis of information literacy}

The following description is analyzed by the deviation analysis of regional variation, information environment, and use hours per week of related facility, background difference and information literacy.

\subsubsection{Regional variation and information literacy}

Primary school students which lived in areas with various extents of urbanization had notable differences in the types of "library literacy", "media literacy", "computer literacy", "network literacy" and "overall information literacy". Comparisons revealed that students living in urban and township areas had better levels of "library literacy", "media literacy", "computer literacy", "network literacy", and "overall information literacy" than students living in the countryside; in addition, the information literacy performance of students living in urban and township areas showed no evident differences for each scale. The level of information literacy of students living in the countryside must be raised as it is considerable lower. Moreover the level of information literacy of students living in urban areas was higher than that of students living in nonurbanized areas. 
Table 3: Variable analysis of regional variations and information literacy.

\begin{tabular}{|c|c|c|c|}
\hline \multirow{2}{*}{ Type of literacy } & \multicolumn{2}{|c|}{ Residential area } & $\begin{array}{c}\text { Degree of } \\
\text { urbanization of the } \\
\text { school }\end{array}$ \\
\cline { 2 - 4 } & F-test & $\begin{array}{c}\text { Scheffè's test } \\
\text { (afterward) }\end{array}$ & F-test \\
\hline Library literacy & $26.111^{* * *}$ & $1,2>3$ & $11.793^{* *}$ \\
\hline Media literacy & $25.995^{* * *}$ & $1,2>3$ & $15.537^{* * *}$ \\
\hline Computer literacy & $48.573^{* * *}$ & $1,2>3$ & $28.640^{* * *}$ \\
\hline Network literacy & $43.532^{* * *}$ & $1,2>3$ & $21.656^{* * *}$ \\
\hline Information literacy & $60.171^{* * *}$ & $1,2>3$ & $32.018^{* * *}$ \\
\hline$p<0.05 ;^{* *} p<0.01 ;{ }^{* * *}$ & $p<0.001 ; 1$, urban; 2, township; 3, countryside.
\end{tabular}

\subsubsection{Information environment and information literacy}

Whether the students have computer facilities and on-line Internet access at home and the seniority of using the network there showed notable differences in the scales of "library literacy", "media literacy", "computer literacy", "network literacy", and "overall information literacy". This shows that the information literacy of students varies according to whether there are computer facilities and on-line Internet access at home and the seniority of using the network.

Table 4: Variable analysis of information environment and information literacy.

\begin{tabular}{|c|c|c|c|c|}
\hline \multirow[t]{2}{*}{ Type of literacy } & $\begin{array}{c}\text { Whether } \\
\text { there is a } \\
\text { computer at } \\
\text { home }\end{array}$ & $\begin{array}{l}\text { Whether } \\
\text { on-line } \\
\text { access is } \\
\text { available at } \\
\text { home }\end{array}$ & \multicolumn{2}{|c|}{$\begin{array}{l}\text { Seniority of using the } \\
\text { network }\end{array}$} \\
\hline & F-test & F-test & F-test & $\begin{array}{c}\text { Scheffè's } \\
\text { test } \\
\text { (afterward) }\end{array}$ \\
\hline Library literacy & $70.513^{* * *}$ & $56.695^{* * *}$ & $18.818^{* * *}$ & $\begin{array}{c}3,4,5>1 \\
2\end{array}$ \\
\hline Media literacy & $71.033^{* * *}$ & $60.798^{* * *}$ & $24.562^{* * *}$ & $\begin{array}{c}3,4,5>1 \\
2\end{array}$ \\
\hline Computer literacy & $105.799^{* * *}$ & $71.797^{* * *}$ & $37.726^{* * *}$ & $\begin{array}{c}3,4,5>1 \\
2\end{array}$ \\
\hline Network literacy & $105.521^{* * *}$ & $61.929^{* * *}$ & $22.678^{* * *}$ & $\begin{array}{c}2,3,4,5> \\
1\end{array}$ \\
\hline $\begin{array}{c}\text { Information } \\
\text { literacy }\end{array}$ & $150.688^{* * *}$ & $105.469^{* * *}$ & $43.599^{* * *}$ & $\begin{array}{c}3,4,5>1 \\
2\end{array}$ \\
\hline
\end{tabular}

$p<0.05 ;{ }^{* *} p<0.01 ;{ }^{* * *} p<0.001 ; 1,<1$ year; 2, 1 2 years; 3, 3 4 years; 4, $5 \sim 6$ years; $5, \geq 7$ years. 


\subsubsection{Background differences and information literacy}

The scales of "library literacy", "network literacy", and "overall information literacy" showed notable differences according to the gender of the students. But no significant differences on the scales of "media literacy" and "computer literacy" were noted for different genders.

Students with various rankings in the class, with different social and economic statuses, and whether there was a communicating objective in the family showed notable variations on the scales of "library literacy", "media literacy", "computer literacy", "network literacy", and "overall information literacy". Comparisons revealed that the performance of information literacy for those students with higher social and economic status was better, the performance for those students with medium social and economic status was next, and the performance of students with lower social and economic status was the lowest. This means that the performance of information literacy for students can be improved by upgrading the family's social and economic status.

Table 5: Variable analysis of background differences and information literacy.

\begin{tabular}{|c|c|c|c|c|c|}
\hline \multirow[t]{2}{*}{$\begin{array}{l}\text { Type of } \\
\text { literacy }\end{array}$} & Gender & Grade & \multicolumn{2}{|c|}{$\begin{array}{c}\text { Family's social and } \\
\text { economic status }\end{array}$} & $\begin{array}{l}\text { Whether } \\
\text { there is } \\
\text { communic } \\
\text { ation } \\
\text { within the } \\
\text { family }\end{array}$ \\
\hline & F-test & F-test & F-test & $\begin{array}{c}\text { Scheffè's } \\
\text { test } \\
\text { (afterward) }\end{array}$ & F-test \\
\hline $\begin{array}{l}\text { Library } \\
\text { literacy }\end{array}$ & $7.875^{* *}$ & $22.715^{* * *}$ & $47.777^{* * *}$ & $3,2>1$ & $45.353^{* * *}$ \\
\hline $\begin{array}{c}\text { Media } \\
\text { literacy }\end{array}$ & 3.616 & $19.343^{* * *}$ & $79.850^{* * *}$ & $3,2>1$ & $55.077^{* * *}$ \\
\hline $\begin{array}{c}\text { Computer } \\
\text { literacy }\end{array}$ & 0.135 & $64.555^{* * *}$ & $133.693^{* * *}$ & $3,2>1$ & $84.567^{* * *}$ \\
\hline $\begin{array}{c}\text { Network } \\
\text { literacy }\end{array}$ & $23.171^{* * *}$ & $54.601^{* * *}$ & $87.299^{* * *}$ & $3,2>1$ & $83.413^{* * *}$ \\
\hline $\begin{array}{c}\text { Information } \\
\text { literacy }\end{array}$ & $7.884^{* *}$ & $65.272^{* * *}$ & $154.760^{* * *}$ & $3,2>1$ & $113.634^{* * *}$ \\
\hline
\end{tabular}

medium social and economic status; 3 , high social and economic status.

\section{Conclusions}

This article used the current status and factors which influence the information literacy of primary school students in Taiwan to explore the characteristics of the 
current status of information literacy of these Taiwanese students. The following conclusions were reached after the final results were analyzed.

\section{Differences existing within the content of information literacy}

The overall performance of information literacy of students was above the average standard, but some differences existed within the content of information literacy. The performance level of network literacy was the highest of all; the performances of library literacy and media literacy were next; and the standard of computer literacy was relatively low. This shows that the performance of computer literacy by students has certain discrepancies compared to other literacy performances; thus this is an area which should be focused on.

2. Information literacy has the following unequal tendencies of social structure of the digital divide

From a literature review, it was found that the digital divide of individuals was influenced by factors of residential area, various social and economic backgrounds, gender, age, educational level, income level, and whether it was an urban or rural area, which were responsible for the variations. From the observation of information literacy for primary school students, this study found that the factors impacting the digital divide exist in the performance of information literacy; at the same time, therefore it is worthy of stressing the unequal tendency of social structure of the digital divide which was followed by information literacy.

3. Elimination of the digital divide should emphasize upgrading the level of information literacy

From the study results, it was learned that more than $80 \%$ of students' families have computer facilities and $66 \%$ of students have on-line Internet access at home, which shows that the accessibility of information technology and content for students has improved. Therefore the information literacy degree of individuals has surpassed the accessibility of information facilities and content to become the most important influential factor of the digital divide. Therefore the government should adjust its policy direction for eliminating the digital divide by upgrading the information literacy degree of people to truly and effectively eliminate the phenomenon of the digital divide.

\section{References}

[1] Horton, J. R., Information literacy vs. computer literacy, Bulletin of the American Society for Information Science, 9(4):6, 1983.

[2] Hess, F. M. \& Leal, D. L., A shrinking digital divide? The provision of classroom computers across urban school systems, Social Science Quarterly, 84, 765-778, 2001.

[3] Irving, L., Falling through the net: defining the digital divide - a report on telecommunications and information technology gap in America. Washington, DC: National Communications and Information 
Administration, US Department of Commerce. July, 1999, Retrieved January 2, 2004, from , 1999.

[4] Leigh, P. R., Electric connections and equal opportunities: an analysis of telecommunications distribution in public schools, Journal of Research on Computing in Education, 32, 108-127, 1999.

[5] McClure, C. R., Network literacy: a role for libraries, Information Technology and Libraries, 13(2), 116-117, 1994.

[6] OECD, Understanding The Digital Divide, January 2, 2004, from , 2001.

[7] Shelly, G. B., Cashman, T. J., \& Waggoner, G. A., Using computer: a gateway to information. Danvers, MA: Boyd \& Fraser Publishing Company, 1996.

[8] Turock, B. J., Who will drive national information policy in the twentyfirst century? Journal of Information, Communication and Library Science 2(1), 4-10, 1995.

[9] US Department of Commerce, Falling through the net $\Pi$ : new data on the digital divide, January 2, 2004, from , 1997.

[10] WSIS, Declaration of Principles and Plan of Action, April 15, 2004, from, 2003. 